\title{
Liver Function Tests: Biochemical Overview for Clinical Correlation
}

\author{
Joan B Kumar ${ }^{1}$, BK Manjunatha Goud², Archana Kumar ${ }^{3}$
}

\begin{abstract}
Aim and objective: To seamlessly integrate the biochemical knowledge and clinical application of liver function tests (LFTs) for easy reference. Background: The LFTs are one of the key investigations done during patient care. Several times during the patient workup, the complete panel of tests is done which is not necessary and adds extra financial burden on the patients. Medical students and young doctors should be aware of the clear indication of tests, to diagnose the condition and treat it accordingly. Healthcare professionals must use these test results in the proper perspective of patient history and physical examination to arrive at the correct diagnosis.

Conclusion and clinical significance: This article highlights the main parameters tested in LFTs and their interpretation in a convenient and easily accessible format.

Keywords: Biochemical parameters, Clinical biochemistry, Liver function test.

Indian Journal of Medical Biochemistry (2021): 10.5005/jp-journals-10054-0171
\end{abstract}

\section{BACKGROUND AND INTRODUCTION}

The liver is one of the largest organs and is very important for various functions including metabolism and excretion of toxic and waste compounds from the body. ${ }^{1}$ All the compounds ingested are under the control of the liver for their safety and flow into the systemic circulation. ${ }^{2}$

The liver is one of the most heterogeneous organs, both functionally and structurally complex after the brain. The liver is involved in almost all vital metabolic functions including the uptake, metabolism, and excretion of carbohydrates, proteins, fats, cholesterol, fat-soluble vitamins, etc. ${ }^{3-6}$

During embryological development, the ventral foregut endoderm gives rise to the liver. ${ }^{7}$ The liver weighs roughly $1.5 \mathrm{~kg}$ which is around $2.5 \%$ of adult body weight. ${ }^{8}$ Histologically, the basic functional unit of the liver is the lobule which is hexagonal in shape with a hepatic venules centrally (also known as a central vein) surrounded by about 4-6 portal areas. ${ }^{2}$ This uniform arrangement is referred to as an "isotropic parenchyma". 9

Previously, the liver has been divided into right, left, quadrate, and caudate segments, but a recent update has suggested that the liver can be subdivided into nine segments based on the vascular and ductal branching patterns. Clinically, it is important to know this compartmental pattern to understand lobar or intralobar deterioration related to interruption of the blood supply and to enable any surgical procedure if necessary. ${ }^{10,11}$

At any given period of time, the liver contains blood equal to almost $25 \%$ of the cardiac output. The liver receives blood from the portal vein and the hepatic artery. The portal vein supplies about $70 \%$ of the blood flow and $40 \%$ of the oxygen while the hepatic artery supplies $30 \%$ of the flow and $60 \%$ of the oxygen. ${ }^{6}$ The liver has numerous types of cells with varying functions as shown in Table 1 along with the extracellular matrix (ECM) which has the following components, matrix metalloproteinases; the glycoproteins laminin, fibronectin, vitronectin, undulin, nidogen (entactin); and proteoglycans such as heparan sulfate. ${ }^{6,11}$ This is important in the regulation and adjustment of hepatic function as $5-10 \%$ of the liver is collagen. \begin{tabular}{l}
\hline 'Department of Physiology, RAK Medical and Health Sciences \\
University, Ras Al khaimah, United Arab Emirates \\
${ }^{2}$ Department of Biochemistry, RAK Medical and Health Sciences \\
University, Ras AI Khaimah, United Arab Emirates \\
${ }^{3}$ Pondicherry Institute of Medical Sciences, Puducherry, India \\
Corresponding Author: Joan B Kumar, Department of Physiology, RAK \\
Medical and Health Sciences University, Ras Al khaimah, United Arab \\
Emirates, Phone: +971 0503223905, e-mail: drjoank@gmail.com \\
How to cite this article: Kumar JB, Goud BKM, Kumar A. Liver Function \\
Tests: Biochemical Overview for Clinical Correlation. Indian J Med \\
Biochem 2021;25(1):31-37. \\
Source of support: Nil \\
Conflict of interest: None
\end{tabular}

The other cells present are the lymphocytes (pit cells); progenitor cells-hepatoblasts; fibroblasts; mesothelia; nerves (unmyelinated); neuroendocrine cells; smooth muscle cells in blood vessels; hematopoietic cells and blood cells (erythrocytes, leukocytes, etc.)

\section{Important Aspects of Hepatocytes}

Hepatocytes are divided into three zones which have different key enzymes of metabolic pathways, a pattern known as "metabolic zonation". ${ }^{24}$ The zonation preserves the body homeostasis as many opposing pathways are separated to avoid rivalry for the substrate. It is also important to know that zonation is dynamic and changes with response to nutrition, drugs, hormones, and other factors. One such example was glutamine synthase once considered as an example for static zonation, but recent finding shows the response outside the zonation area to thyroid hormones. ${ }^{25,26}$

The following are the zones with their importance;

Zone $I$ is a periportal region and it is well perfused and regenerates fast due to the availability of oxygenated blood with 
Table 1: Liver cells and their functions

\begin{tabular}{|c|c|c|}
\hline No & Liver cells & Functions and clinical importance \\
\hline \multirow[t]{7}{*}{1} & $\begin{array}{l}\text { Hepatocytes ( } 60 \% \text { of cells and } 80 \% \text { of volume of } \\
\text { parenchyma) }\end{array}$ & $\begin{array}{l}\text { Known as workhorses of the liver and have all the equipment to carry out } \\
\text { vital functions. }\end{array}$ \\
\hline & & $\begin{array}{l}\text { Involve in the metabolism of energy sources and synthesizes the serum } \\
\text { proteins and coagulation factors. }{ }^{2}\end{array}$ \\
\hline & & Detoxify and excrete cholesterol as bile (average about $15 \mathrm{~mL} / \mathrm{kg} /$ day). ${ }^{4}$ \\
\hline & & $\begin{array}{l}\text { Involve in steroid hormone and xenobiotic metabolism using } \\
\text { mono-oxidases. }^{13}\end{array}$ \\
\hline & & Clinical point: \\
\hline & & $\begin{array}{l}\text { As the age increases the number of hepatocytes diminish with hypertrophy } \\
\text { and increased polyploidy, lysosomes, and smooth endoplasmic reticulum. }{ }^{4}\end{array}$ \\
\hline & & $\begin{array}{l}\text { Whereas mitochondria and peroxisomes remain unchanged with age } \\
\text { leading to decreased ability of drug metabolism. }\end{array}$ \\
\hline 2 & Biliary epithelial & $\begin{array}{l}\text { The epithelium of the biliary tract acts as a lining channel for bile flow and } \\
\text { is also effective communicators with surrounding cells. They also produce } \\
\text { mediators responding to injury and cell growth. }\end{array}$ \\
\hline \multirow[t]{6}{*}{3} & Endothelial sinusoids, arteries, veins, and lymphatics & $\begin{array}{l}\text { The sinusoidal endothelial cells (SECs) constitute } 20 \% \text { of the liver cells and } \\
\text { act as a barrier between blood and hepatocytes to filter fluids, solutes, and } \\
\text { particles between the blood and space of Disse. }{ }^{14,15}\end{array}$ \\
\hline & & Clinical importance: \\
\hline & & $\begin{array}{l}\text { Fenestrae play an important role in the development of atherosclerosis, cir- } \\
\text { rhosis, and implantation of tumor metastases. }{ }^{14,15}\end{array}$ \\
\hline & & $\begin{array}{l}\text { Smaller fenestrae lead to less cholesterol being removed from blood thereby } \\
\text { increasing the risk for atherosclerosis development. }\end{array}$ \\
\hline & & $\begin{array}{l}\text { They can engulf smaller size particles and could play a role in the clearance } \\
\text { of viruses. }{ }^{16}\end{array}$ \\
\hline & & $\begin{array}{l}\text { In addition, they also function as antigen-presenting cells and secrete } \\
\text { cytokines and eicosanoids. }{ }^{17}\end{array}$ \\
\hline \multirow[t]{3}{*}{4} & Kupffer cells & $\begin{array}{l}\text { The liver contains large amounts of Kupffer cells derived from monocytes, } \\
\text { which form } 15 \% \text { of the liver cells and are actively phagocytic.,11,18 }\end{array}$ \\
\hline & & $\begin{array}{l}\text { They are found within the sinusoids and are in constant activation because of } \\
\text { contact with gut-derived particles. When activated, they secrete an immense } \\
\text { range of inflammatory mediators such as cytokines, reactive oxygen species, } \\
\text { eicosanoids, and nitric oxide. }{ }^{17}\end{array}$ \\
\hline & & 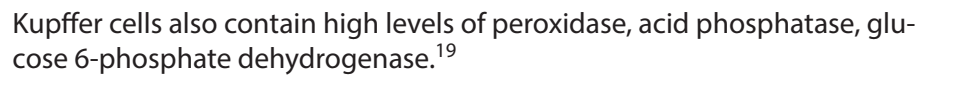 \\
\hline \multirow[t]{2}{*}{5} & Hepatic stellate cells_-HSC (Ito or fat-storing cells) & $\begin{array}{l}\text { Constitute around } 5 \% \text { of cells and plays a major role in regeneration, fibro- } \\
\text { genesis, and disease such as cirrhosis. }{ }^{20-23}\end{array}$ \\
\hline & & $\begin{array}{l}\text { HSC normally produces an extracellular matrix. They also control microvas- } \\
\text { cular tone, store, and process vitamin A and lipid. They can be activated } \\
\text { to myofibroblasts capable of producing desmin and smooth muscle actin } \\
\text { filaments. }\end{array}$ \\
\hline
\end{tabular}

nutrients. It performs a vital role in oxidative metabolisms such as beta-oxidation of fatty acids, synthesis of glucose from noncarbohydrate sources (gluconeogenesis), bile and cholesterol synthesis, and amino acid breakdown.

Zone II is demarcated as the pericentral region of the hepatocytes and zone II sits between zones I and III.

Zone III has the poorest perfusion since it is furthermost from the portal triad. It performs the functions of detoxification and biotransformation of drugs, ketone body formation, glycolysis (breakdown of glucose), lipogenesis, glycogen synthesis for storage, and glutamine synthesis. ${ }^{27}$

\section{Liver Function Tests}

The assessment of liver enzymes is one of the routine investigations done to know the status of the liver in various conditions. The various parameters indicate the different conditions the patient may be suffering. A clear knowledge of liver function tests (LFTs) will save time for the physician to treat. The LFT can be used to diagnose a condition, know the progress of disease and monitor the response to treatment. Basically, the liver disorder can be categorized as prehepatic, hepatic, and post-hepatic conditions.

\section{Prehepatic Condition}

This encompasses any conditions which put more workload on the liver. The liver is functioning normally, i.e., no abnormality, but the disease process lies proximal to the liver.

Example: Red blood cells (RBCs) breakdown leads to the formation of bilirubin which is normally conjugated by the liver for its excretion. If the patient suffers from any condition leading to 
abnormal hemolysis, it will produce more bilirubin and the liver has to do extra work.

Conditions: Malaria, hemolytic anemia, Gilbert's syndrome (decreased hepatic uptake, exacerbated by fasting), Crigler-Najjar syndrome (decreased conjugation), drug-induced, ineffective erythropoiesis, blood transfusion, etc.

\section{Hepatic Condition}

Here, the disease process is in the liver itself. The liver abnormity leads to an inability to conjugate the bilirubin. This also leads increase in certain enzymes in blood circulation which can aid in diagnosis.

Conditions: Alcoholic liver disease, hepatitis of various etiologies including latrogenic, hereditary hemochromatosis, autoimmune hepatitis, primary biliary cirrhosis or primary sclerosing cholangitis, hepatocellular carcinoma, etc.

\section{Post-hepatic condition}

Here, the disease process happens distal to the liver, i.e., obstruction to the biliary tract. This also leads to an increase in various enzymes lining the biliary canaliculi. Conditions: Biliary obstruction due to impacted stones, gallbladder stones, pancreatic tumor, druginduced cholestasis, etc.

The LFTs can be broadly divided into:

\section{Tests to Detect Hepatic Injury}

Measurement of bilirubin, serum bilirubin total, unconjugated bilirubin, conjugated bilirubin, urinary bilirubin, urinary urobilinogen, and specific enzymes.

\section{Tests to Assess Hepatic Function}

Serum albumin levels, prothrombin time (PT), etc.

The location and elevation of AST and ALT have significance with regard to various liver disorders. As mentioned the AST has mitochondrial and cytoplasmic fractions, the latter contributing to most of circulating serum AST. ${ }^{30}$ Conversely, ALT is found only in cytoplasm and specific to liver tissue. This makes an elevated ALT more specific for hepatocellular injury than AST apart from myopathy diseases. ${ }^{31}$ The outline of some parameters of liver function tests have been depicted in Table 2 with their clinical importances.

\section{Discussion}

The LFTs are one of the key investigations done during patient care. Medical students and young doctors should be aware of clear indications of tests, to diagnose the condition and treat it accordingly. The LFTs are easy to interpret with a proper understanding of parameters and its uses.

The term LFT is a misnomer as these tests determine liver injury rather than hepatobiliary function. These tests may also indicate other organ injuries. This does not rule out the use of these tests in clinical practice as the combination of patient history, examination, and tests form the triad for accurate diagnosis.

Many times the LFTs are ordered for non-specific symptoms with the likelihood of minimal or no link with liver disease. This will add up the unnecessary financial burden to the patient care. ${ }^{32}$
This also corroborated with studies suggesting that many patients referred to hospitals with LFTs did not have significant evidence of liver problems. ${ }^{33}$

Most patients are diagnosed after developing complications such as liver failure or portal hypertension. In this late/preterminal stage, the tests such as bilirubin, albumin, and platelet count may be obviously abnormal. Studies have suggested that in necroinflammatory hepatitis diseases liver enzymes are elevated, ${ }^{34,35}$ and in apoptotic diseases liver enzymes may be normal or elevated, but the amount of deviation is not related to the stage of progression from simple fatty liver to cirrhosis. ${ }^{36}$

The type of bilirubin increase may not give us the exact etiology but supports the probable diagnosis. The rise of unconjugated bilirubin should be looked into the following differential diagnosis of increased hemolysis, decreased conjugation, severe hepatocellular damage, and hepatobiliary obstruction in later stages.

Abnormal liver enzyme levels may signal liver damage or alteration in bile flow. There will be an isolated abnormality in parameters discussed even in healthy patients and leads to challenges to physicians and may lead to performing costlier tests which may prove unnecessary. ${ }^{37}$

The hepatocellular injury is always confirmed by the raise of enzymes along with other parameters. The release of enzymes is due to altered cell membrane permeability and the concentration of enzymes in hepatocytes zones will indicate the exact site of damage. The viral and autoimmune hepatitis involves the periportal hepatocytes, which have more ALT. The ischemic and toxic damage to the liver involves the central zone which has more AST. That is why we need to use AST/ALT ratio, also known as the De Ritis ratio in evaluating the various liver diseases. ${ }^{38}$

The toxic levels of acetaminophen lead to saturation of sulfate and glucuronide metabolic pathways and pushes more acetaminophen metabolism toward the cytochrome $\mathrm{P} 450$ pathway that results in the formation of the toxic metabolite $N$-acetyl-pbenzoquinoneimine (NAPQ1). The study also showed acute liver failure is more common in chronic alcohol abusers and caution must be taken while treating such patients. ${ }^{39}$

In these patients, cytochrome $\mathrm{P}-450$, principally cytochrome CYP2E1, metabolizes acetaminophen into a toxic metabolite, which is detoxified by glutathione. In the case of alcoholics, activation of CYP2E1 for the detoxification of ethanol also metabolizes acetaminophen into its toxic metabolites. ${ }^{40}$

In alcoholic hepatitis, AST is higher than ALT. It should be noted that high AST/ALT in acute hepatitis ( $>1.5)$ is indicative of a potential fulminant course and a ratio of $>1.0$ in chronic liver disease indicates advanced fibrosis. ${ }^{40,41}$

Alcohol consumption can lead to a range of liver diseases varying from fatty liver to alcoholic hepatitis to cirrhosis. Studies have suggested that AST/ALT ratio 2-3:1 raises the probable diagnosis of alcoholic liver disease. This can be explained as there is a decrease in plasma pyridoxal 5'-phosphate which affects the ALT activity without affecting the AST activity. ${ }^{42}$ Studies have also shown that once alcohol abstinence is observed with adequate nutrition the levels of pyridoxal 5'-phosphate returns to normal and thereby normalizes the ALT level. ${ }^{43-45}$

The rise of the AST/ALT ratio is also seen in cholecystitis following a gallstone impaction in the distal cystic duct or choledocholithiasis apart from alcoholic liver disease. However, the difference is once 
Table 2: LFTs and their clinical significance

\begin{tabular}{ll}
\hline Parameter & Function \\
\hline Total bilirubin & Measurement of unconjugated and conjugated. \\
$\begin{array}{l}\text { Unconjugated } \\
\text { bilirubin }\end{array}$ & $\begin{array}{l}\text { Released from RBCs during the } \\
\text { breakdown. } \\
\text { Being water-insoluble binds with albumin for its transport to liver } \\
\text { for conjugation process. }\end{array}$ \\
Conjugated bilirubin & $\begin{array}{l}\text { The liver conjugates the bilirubin to become water-soluble } \\
\text { for its excretion with glucuronic acid by the enzyme UDP- } \\
\text { glucuronyltransferase (UGT). } \\
\text { Normally not seen in blood in high quantities as the process } \\
\text { happens in liver cells. }\end{array}$ \\
& \\
& \\
Urinary urobilinogen & $\begin{array}{l}\text { Normally conjugated bilirubin excreted through bile reaches the } \\
\text { intestine (duodenum), part of it will be reabsorbed and other } \\
\text { parts by the action of intestinal bacteria lead to the formation of } \\
\text { stercobilinogen and urobilinogen. }\end{array}$
\end{tabular}

Stercobilinogen Formed in intestine

Urine bilirubin Normally absent in urine.

Clinical importance

Suggestive of liver disorder.

It will not provide the exact location of the disease, i.e., prehepatic or hepatic.

Increased level in blood indicates prehepatic conditions.

Being water-insoluble is never excreted in the urine.

Increased levels in blood indicates intrahepatic obstruction, extrahepatic obstruction.

Being water-soluble excreted in urine as urinary bilirubin. A pathogenic feature of obstructive jaundice.

Note:

Only conjugated bilirubin indicates obstructive jaundice outside the liver.

Both conjugated and unconjugated bilirubin increase indicates pathology within the liver. Normally present in urine.

Increased amount indicates prehepatic condition $(+++)$ or hepatic condition (++).

Absence in urine indicates obstructive jaundice. Normally present in stools.

Absence (clay color stools) is a direct indication of obstructive conditions.

Seen in obstructive conditions of the biliary tract. A minimal amount is also seen in hepatic conditions which shows an increase in unconjugated and conjugated bilirubin in the blood.

Enzymes

Alanine transaminase Belong to aminotransferases or transaminases group of enzymes.

Raised levels indicate hepatocellular injury.

(ALT)

Produced by hepatocytes and direct indicator of hepatic injury.

Also located in other tissues such as the heart, kidney, and skeletal muscle but high in the liver. ${ }^{28}$

Levels vary with exercise.

Aspartate

Belong to aminotransferases or transaminases group of enzymes.

transaminase (AST) Two isoenzyme forms.

In hepatocytes, it is a mitochondrial enzyme and in skeletal

muscle, heart, and kidney it is cytosolic.

Released by hepatic cell damage.

Non-specific indicator of hepatocellular damage.

Alkaline phosphatase Produced by cells lining the bile ducts and canaliculi.

(ALP) There are four isoenzyme forms based on tissue specificity

Placental alkaline phosphatase (PLALP) also known as Regan isoenzyme

Intestinal alkaline phosphatase (IALP)

Germ cell ALP (GCALP)

Liver/bone/kidney alkaline phosphatase (L/B/K ALP) ${ }^{29}$

Released during cholestasis.

Gamma-glutamyl Apart from the liver and biliary epithelial cells present in the

Raised levels indicate biliary obstruction.

Value raised in various conditions other than bile duct diseases, cholestasis, such as bone disease and metastasis, renal condition, physiological during pregnancy, in a growing child, etc. kidney, pancreas, and intestine. 
Contd...

\begin{tabular}{|c|c|c|}
\hline Parameter & Function & Clinical importance \\
\hline & & $\begin{array}{l}\text { Should be used along with ALP as chronic } \\
\text { alcoholism increases the levels with hepatic } \\
\text { enzyme induction. }\end{array}$ \\
\hline & & $\begin{array}{l}\text { Drugs such as phenytoin, rifampicin increase the } \\
\text { levels. }\end{array}$ \\
\hline Serum albumin & Synthesized by liver only. Half-life is 21 days. & Decreased levels indicate chronic liver disease. \\
\hline Prothrombin & Synthesized by liver only. & Prothrombin time increases in acute liver injury. \\
\hline \multirow[t]{2}{*}{ Serum ceruloplasmin } & An acute-phase protein, synthesized by the liver & $\begin{array}{l}\text { Raised levels seen physiologically in pregnancy } \\
\text { and being an acute phase protein rise seen in } \\
\text { infections, rheumatoid arthritis, non-Wilson } \\
\text { disease, and obstructive jaundice. }\end{array}$ \\
\hline & & $\begin{array}{l}\text { Low levels are seen in neonates, protein-energy } \\
\text { malnutrition (Kwashiorkor and marasmus), } \\
\text { protein-losing enteropathy, aceruloplasminemia. }\end{array}$ \\
\hline \multirow[t]{2}{*}{$\begin{array}{l}\text { Procollagen iii } \\
\text { peptide }\end{array}$} & & $\begin{array}{l}\text { Raise seen in hepatic fibrosis, inflammation, and } \\
\text { necrosis. }\end{array}$ \\
\hline & & $\begin{array}{l}\text { Need to do serial measurements to follow-up on } \\
\text { the chronic liver disease. }\end{array}$ \\
\hline Alpha 1 antitrypsin & $\begin{array}{l}\text { Is a glycoprotein, synthesized by the liver, a serine proteinase } \\
\text { inhibitor. }\end{array}$ & $\begin{array}{l}\text { Raised in inflammatory conditions, pregnancy, } \\
\text { and use of oral contraceptive pills. }\end{array}$ \\
\hline Alpha-fetoprotein & $\begin{array}{l}\text { Seen in early gestation in the fetus at high concentration later } \\
\text { decreasing to very low levels. }\end{array}$ & $\begin{array}{l}\text { Raise is characteristic of hepatocellular } \\
\text { carcinoma. }\end{array}$ \\
\hline
\end{tabular}

the disimpaction of the stone occurs, there is a reversal of this ratio. In advanced hepatic fibrosis, there is a reversal in the AST:ALT ratio in chronic when compared with acute hepatitis. ${ }^{46}$

Studies have suggested that aminotransferases levels vary with various factors such as age, gender, race, and body mass index. ${ }^{47}$ The levels will be high in obese, patients on dialysis, African American males and defect in clearance in some populations and losing weight have shown the decline in ALT levels. ${ }^{48-50}$

Occupations like mushroom picking (Amanita phalloides) and those involved in the chemical industry (vinyl chloride) could lead to aminotransferase elevation. ${ }^{51}$

In cases of post-obstructive conditions, the most commonly used enzyme assay is alkaline phosphatase (ALP) and must be complemented with gamma GGT. The gamma GGT alone cannot be used for the diagnosis of cholestasis as its diffusely located in the endoplasmic reticulum of bile duct cells. In conjugation with $A L P$, it indicates the raise of enzymes is specific and not derived from other organ damage. ${ }^{52}$

The rise of unconjugated bilirubin without conjugated bilirubin indicates extrahepatic origin such as hemolysis. Without hemolysis, we can suspect the case of a defect in hepatic cells in terms of conjugation process or excretion. On the other hand, high levels of conjugated bilirubin are suggestive of biliary obstruction with various etiologies. We should also keep in mind the hereditary disorders with defects of secretion, i.e., Dubin-Johnson and Rotor syndrome.

It has been shown that increased total serum bilirubin with prolonged PT have poor outcomes in alcoholic hepatitis patients. ${ }^{53}$

The serum albumin levels indicative of chronic liver diseases, before the increase in bilirubin or prothrombin the decline in albumin levels, indicates advanced liver cirrhosis. It should also be noted that albumin levels decrease in other conditions such as malnutrition, nephrotic syndrome, and chronic infections.

Studies have shown the level of albumin correlates with the prognosis of patients with or without ascites.
The rate of albumin synthesis correlates with the Child-Turcotte or Child-Pugh score. ${ }^{54}$

Hormones such as corticosteroids and thyroid hormone stimulate albumin synthesis by stimulating the concentration of albumin mRNA and tRNA in hepatocytes. ${ }^{55}$

In ascites, there may be a normal synthesis of albumin but the levels may appear reduced because of an increased volume of distribution. ${ }^{56,57}$

The PT is the best indicator of acute injury to liver cells. Apart from factor VIII, all coagulation factors are synthesized by the liver and obviously will have an abnormal coagulation profile in liver diseases. It should be borne in mind that most clotting factors are dependent on vitamin $\mathrm{K}$ and deficiency or inhibition of vitamin $\mathrm{K}$ alters the PT. The vitamin K deficiency is seen in patients with chronic cholestasis, fat malabsorption conditions. ${ }^{58}$

Prothrombin time serves as a prognostic indicator for acute and chronic hepatocellular disease. In acute hepatocellular disease elongation of PT suggests an increased likelihood of acute hepatic failure. The PT also is a predictor of acetaminophen toxicity, acute alcoholic hepatitis, and poor prognosis in chronic liver disease. ${ }^{59}$

Prolongation of PT is also seen in hypovitaminosis $\mathrm{K}$ and parenchymal disease. In the former condition, it returns to normal or improves within 24 hours of single parenteral injection of vitamin $\mathrm{K} 1$, whereas in the latter condition it shows only minimal improvement. But patients with an extrahepatic obstruction such as extra hepatic biliary atresia (EHBA) would respond promptly to a single injection of vitamin $\mathrm{K} 1{ }^{60}$

\section{Conclusion}

This article highlights the importance and relevance of liver function disease in clinical settings. Knowing the different parameters which can be measured and the conditions in which they are altered will help the healthcare professionals in making an accurate diagnosis. This knowledge would also prevent the LFT from being unnecessarily ordered saving both time and money for the patients. 


\section{References}

1. Ozougwu JC, Eyo JE. Hepatoprotective effects of Allium cepa extracts on paracetamol-induced liver damage in rat. Afr J Biotechnol 2014;13(26):2679-2688. DOI: 10.5897/AJB2014.13815.

2. Allen SE. The liver: anatomy, physiology, disease and treatment. USA: North Eastern University Press; 2002.

3. Bloom W, Fawcett DW. Liver and gallbladder. In: A textbook of histology Bloom W, Fawcett DW, ed., Philadelphia: W. B. Saunders; 1975. pp. 688-718.

4. Jones AL, Spring-Mills E. The liver and gallbladder. In: Histology Weiss L, ed., New York: Elsevier Biomedical; 1983. pp. 707-735.

5. LaBrecque $D$. Liver regeneration: a picture emerges from the puzzle. Am J Gastroenterol 1994;89(8 Suppl):S86-S96.

6. Burt AD, Day CP. Pathophysiology of the liver. In: Pathology of the Liver MacSween RNM, Burt AD, Portmann BC, et al., ed., New York: Churchill Livingstone; 2002. pp. 67-105.

7. Watt AJ, Zhao R, Li J, et al. Development of the mammalian liver and ventral pancreas is dependent on GATA4. BMC Developmen Biol 2007;7(1):37-45. DOI: 10.1186/1471-213X-7-37.

8. Moore KL, Dalley AF. Clinically oriented anatomy. 5th ed., Lippincott Williams and Wilkins; 2006. p. 1209.

9. Matsumoto T, Kawakami M. The unit-concept of hepatic parenchyma - a re-examination based on angioarchitectural studies. Acta Pathol Jpn 1982;32(Suppl 2):285-314.

10. Kogure $K$, Ishizaki $M$, Nemoto $M$, et al. A comparative study of the anatomy of rat and human livers. J Hepatobiliary Pancreat Surg 1999;6(2):171-175. DOI: 10.1007/s005340050101.

11. MacSween RNM, Desmet VJ, Roskams T, et al. Developmental anatomy and normal structure. In: Pathology of the liver MacSween RNM, Burt $A D$, Portmann BC, et al., ed., New York: Churchill Livingstone; 2002. pp. 1-66.

12. Jeejeebhoy K, Phillips MJ. Isolated mammalian hepatocytes in culture. Gastroenterology 1976;71(6):1086-1096. DOI: 10.1016/S00165085(76)80065-0.

13. Sirica $A E$, Pitot AC. Drug metabolism and effects of carcinogens in cultural hepatic cells. Pharmacolog Re 1979;31(3):205-228.

14. Braet $F$, Wisse $E$. Structural and functional aspects of liver sinusoidal endothelial cell fenestrae: a review. Comp Hepatol 2002;1(1):1. DOI: 10.1186/1476-5926-1-1.

15. Smedsrod B. Clearance function of scavenger endothelial cells. Comp Hepatol 2004;3(Suppl 1):S22. DOI: 10.1186/1476-5926-2S1-S22.

16. Breiner KM, Urban S, Schaller H. Endothelial cell-mediated uptake of a hepatitis $B$ virus: a new concept of liver targeting of hepatotropic microorganisms. Hepatology 2001;34(4):803-808. DOI: 10.1053/ jhep.2001.27810.

17. Kmiec Z. Co-operation of liver cells in health and diseases. Adv Anatomy, Embryol Cell Biol 2001;161:3-12.

18. Knook DL, Blansjaar N, Sleyster EC. Isolation and characterization of Kupffer and endothelial cells from the rat liver. Experimen Cell Res 1977;109(2):317-329. DOI: 10.1016/0014-4827(77)90011-8.

19. Munthe-Kaas AC, Berg T, Seglen PO, et al. Distribution of lysosomal enzyme in different types of rat liver cells. Experimen Cell Res 1976;99(1):146-154. DOI: 10.1016/0014-4827(76)90689-3.

20. Ratziu V, Friedman SL. Pathobiology of hepatic stellate cells. In: Functional heterogeneity of liver tissue: from cell lineage diversity to sublobular compartment-specific pathogenesis Vidal-Vanaclocha F, ed., Austin: R. G. Landes Company; 1997. pp. 133-160.

21. Fehrenbach $\mathrm{H}$, Weiskirchen $\mathrm{R}$, Kasper $\mathrm{M}$, et al. Upregulated expression of the receptor for advanced glycation end products in cultured rat hepatic stellate cells during transdifferentiation to myofibroblasts. Hepatology 2001;34(5):943-952. DOI: 10.1053/jhep.2001.28788.

22. Albanis E, Safadi R, Friedman SL. Treatment of hepatic fibrosis: almost there. Curr Gastroenterol Rep 2003;5(1):48-56. DOI: 10.1007/s11894003-0009-7.

23. Mabuchi A, Mullaney I, Sheard P, et al. Role of hepatic stellate cells in the early phase of liver regeneration in rat: formation of tight adhesion to parenchymal cells. Comp Hepatol 2004;3(Suppl 1):S29. DOI: 10.1186/1476-5926-2-S1-S29.

24. Katz N, Jungermann $\mathrm{K}$, Seylers $\mathrm{H}$. Autoregulatory shift from fructolysis to lactate gluconeogenesis in rat hepatocyte suspensions. The problem of metabolic zonation of liver parenchyma. Z Physiol Chem 1976;357(3):359-375. DOI: 10.1515/bchm2.1976.357.1.359.

25. Fanti M, Singh S, Ledda-Columbano GM, et al. Tri-iodothyronine induces hepatocyte proliferation by protein kinase a-dependent $\beta$-catenin activation in rodents. Hepatology 2014;59(2014):23092320. DOI: 10.1002/hep.26775.

26. Ippoliti R, Lendaro E, Benedetti PA, et al. Endocytosis of a chimera between human pro-urokinase and the plant toxin saporin: an unusual internalization mechanism. FASEB J 2000;14(10):1335-1344. DOI: 10.1096/fj.14.10.1335.

27. Kalra A, Yetiskul E, Wehrle CJ, et al. Physiology, liver. In: StatPearls [Internet]. Treasure Island (FL): StatPearls Publishing; 2020. Retrieved from: https://www.ncbi.nlm.nih.gov/books/ NBK535438/\#article-24376.s1.

28. Lindena J, Sommerfeld U, Hopfel C, et al. Catalytic enzyme activity concentration in tissues of man, dog, rabbit, guinea pig, rat and mouse. Approach to a quantitative diagnostic enzymology, III. Communication. J Clin Chem Clin Biochem 1986;24(1):35-47. DOI: 10.1515/cclm.1986.24.1.35.

29. Sligbrand T. Present status and future trends of human alkaline phosphatases. Prog Clin Biol Res 1984;166:3-14.

30. Thapa BR, Walia A. Liver function tests and their interpretation. Indian J Pediat 2007;74(7):663-671. DOI: 10.1007/s12098-007-0118-7.

31. Scola RH, Werneck LC, Prevedello DM, et al. Diagnosis of dermatomyositis and polymyositis: a study of 102 cases. Arq Neuropsiquiatr 2000;58(3B):789-799. DOI: 10.1590/s0004$282 \times 2000000500001$.

32. Lilford RJ, Bentham L, Girling A, et al. Birmingham and lambeth liver evaluation testing strategies (BALLETS): a prospective cohort study. Health Technol Assess 2013;17:1-307.

33. Donnan P, McLernon D, Dillon J, et al. Development of a decision support tool for primary care management of patients with abnormal liver function tests without clinically apparent liver disease: a recordlinkage population cohort study and decision analysis (ALFIE). Health Technol Assess 2009;13(25):1-134. DOI: 10.3310/hta13250.

34. Dufour DR, Lott JA, Nolte FS, et al. Diagnosis and monitoring of hepatic injury. II. Recommendations for use of laboratory tests in screening, diagnosis, and monitoring. Clin Chem 2000;46(12):20502068. DOI: 10.1093/clinchem/46.12.2050.

35. Dufour DR, Lott JA, Nolte FS, et al. Diagnosis and monitoring of hepatic injury. I. Performance characteristics of laboratory tests. Clin Chem 2000;46(12):2027-2049. DOI: 10.1093/clinchem/46.12.2027.

36. Williams $R$, Aspinall $R$, Bellis $M$, et al. Addressing liver disease in the UK: a blueprint for attaining excellence in health care and reducing premature mortality from lifestyle issues of excess consumption of alcohol, obesity, and viral hepatitis. Lancet 2014;384(9958):1953-1997. DOI: 10.1016/S0140-6736(14)61838-9.

37. Green RM, Flamm S. AGA technical review on the evaluation of liver chemistry tests. Gastroenterol 2002;123(4):1367-1384. DOI: 10.1053/ gast.2002.36061.

38. De Ritis F, Coltorti M, Giusti G. An enzymic test for the diagnosis of viral hepatitis: the transaminase serum activities. J Infect Dis 1957;101(3):219-223. DOI: 10.1093/infdis/101.3.219.

39. Gómez-Moreno G, Guardia J, Cutando A. Interaction of paracetamol in chronic alcoholic patients. Importance for odontologists. See comment in PubMed Commons below Med Oral Patol Oral Cir Bucal 2008;13(4):E235-E238.

40. Botros M, Sikaris KA. The de ritis ratio: the test of time. Clin Biochem Rev 2013;34(3):117-130.

41. Botros M, Sikaris KA, Lu ZX, et al. The short term prognostic usefulness of the De Ritis ratio. Clin Biochem Rev 2013;34:S18.

42. Erden A, Esmeray K, Karagöz H, et al. Acute liver failure caused by mushroom poisoning: a case report and review of the literature. Int Med Case Rep J 2013;6:85-90. DOI: 10.2147/IMCRJ.S53773. 
43. Nalpas B, Vassault A, Le Guillou A, et al. Serum activity of mitochondrial aspartate aminotransferase: a sensitive marker of alcoholism with or without alcoholic hepatitis. Hepatol 1984;4(5):893-896. DOI: 10.1002/ hep.1840040517.

44. Vernon G, Baranova A, Younossi ZM. Systematic review: the epidemiology and natural history of non-alcoholic fatty liver disease and nonalcoholic steatohepatitis in adults. Aliment Pharmacol Ther 2011;34(3):274-285. DOI: 10.1111/j.1365-2036.2011.04724.x.

45. Giovanni G, Gambino R, Cassader M, et al. Meta-analysis: natural history of non-alcoholic fatty liver disease (NAFLD) and diagnostic accuracy of non-invasive tests for liver disease severity. Ann Med 2011;43(8):617-649. DOI: 10.3109/07853890.2010.518623.

46. Kulkarni A, Garg M, Agrawal RM, et al. Analysis and interpretation of classic liver enzymes. Pract Gastroent 2018;XLII(11):76-86. https:// practicalgastro.com/wp-content/uploads/2019/07/Analysis-andInterpretation-of-Classic-Liver-Enzymes.pdf.

47. Siest G, Schiele F, Galteau MM, et al. Aspartate aminotransferase and alanine aminotransferase activities in plasma: statistica distributions, individual variations, and reference values. Clin Chem 1975;21(8):1077-1087. DOI: 10.1093/clinchem/21.8.1077.

48. Yasuda K, Okuda K, Endo N, et al. Hypoaminotransferasemia in patients undergoing long-term hemodialysis: clinical and biochemical appraisal. Gastroenterol 1995;109(4):1295-1300. DOI: 10.1016/0016-5085(95)90591-x.

49. Palmer M, Schaffner F. Effect of weight reduction on hepatic abnormalities in overweight patients. Gastroenterol 1990;99(5):14081413. DOI: 10.1016/0016-5085(90)91169-7.

50. Vajro $P$, Lofrano MM, Fontanella $A$, et al. Immunoglobulin complexed AST ("macro-AST") in an asymptomatic child with persistent hypertransaminasemia. J Pediatr Gastroenterol Nutr 1992;15(4):458-460. DOI: 10.1097/00005176-199211000-00018.
51. Stapleton JT. Host immune response to hepatitis A virus. J Infect Dis 1995;175(Suppl 1):S9-S14. DOI: 10.1093/infdis/171. supplement_1.s9.

52. Levinson M, Holbert J, Blackwell C, et al. Serum gammaglutamyl transpeptidase: its specificity and clinical value. South Med 1979;72(7):837-841. DOI: 10.1097/00007611-197907000-00021.

53. Pratt DS. Evaluation of liver function. In: Kasper D, Fauci A, Hauser $\mathrm{S}$, et al., ed. Harrison's principles of internal medicine. 19th ed., New York, NY: McGraw-Hill; 2015. pp. 1995-1998.

54. Anderson GF, Barnhart MI. Intracellular localization of prothrombin. Proc Soc Exp Biol Med 1964;116(1):1-4. DOI: 10.3181/00379727-11629142.

55. Jefferson DM, Reid LM, Giambrone MA, et al. Effects of dexamethasone on albumin and collagen gene expression in primary cultures of adult rat hepatocytes. Hepatology 1985;5(1):14-19. DOI: 10.1002/ hep.1840050105.

56. Rothschild MA, Oratz M, Zimmon D, et al. Albumin synthesis in cirrhotic subjects studied with carbonate 14 C. J Clin Invest 1969;48(2):344-349. DOI: 10.1172/JCI105990.

57. Hasch E, Jarnum S, Tygstrup N. Albumin synthesis rate as a measure of liver function in patients with cirrhosis. Arch Intern Med 1967;182(1):38-44. DOI: 10.1111/j.0954-6820.1967. tb11502.x.

58. Kasarala G, Tillmann HL. Standard liver tests. Clin Liver Dis 2016;8(1):13-18. DOI: 10.1002/cld.562.

59. Friedman SF, Martin P, Munoz JS. Laboratory evaluation of the patient with liver disease. Hepatology, a textbook of liver disease. Philedelphia: Saunders Publication; 2003. vol. 1 pp. 661-709.

60. Daniel SP, Marshall MK. Evaluation of the liver: laboratory tests. Schiff's diseases of the liver. 8th ed., USA: JB Lippincott Publications; 1999. pp. 205-239. 